\title{
Література:
}

1. Кодекс України з процедур банкрутства: Закон України від 18.10.2018 p. № 2597-VIII. URL: https://www.zakon.rada.gov.ua/laws/ show/2597-19 (дата звернення: 02.02.2021).

2. Бутирська I. Правовий статус учасників провадження у справі про банкрутства. Підприємництво, господарство і право. 2016. № 12. С. 89-94.

3. Радзивілюк В. В. Запобігання банкрутству (неспроможності): господарсько-правовий аспект : монографія. Ніжин : ТОВ «Видавництво «Аспект-Поліграф», 2013. 532 с.

4. Асеева Н. В. Обеспечение частных и публичных интересов при банкротстве предприятия : монография. Донец. ун-т экономики и права. Донецк : ДонУЭП, 2013. 200 с.

DOI https://doi.org/10.30525/978-9934-26-040-7-26

\section{ЩОДО ОРГАНІЗАЦІЇ ПРОДАЖУ МАЙНА БАНКРУТА}

\author{
Тюріна Ю. Є. \\ адвокат \\ АО «ПРАВОВИЙ ЦЕНТР ХХІ СТ.» \\ м. Київ, Украӥна
}

Продаж майна банкрута $\epsilon$ чи не найважливішим етапом у всій процедурі банкрутства. Безпосередньо продажу майна передує низка організаційних заходів і процедур, які передбачені законодавчо. При цьому, з прийняттям Кодексу України з процедур банкрутства майно банкрута може бути продано виключно шляхом проведення електронних торгів. У зв'язку із цим організація продажу майна банкрута перетерпіла істотних змін. Дотримання умов організації та проведення продажу майна наразі $\epsilon$ запорукою вдосконалення правового інституту банкрутства.

Організація продажу майна банкрута регламентована положеннями Кодексу України з процедур банкрутства (далі - Кодекс) та Порядком організації та проведення аукціонів з продажу майна боржників у справах про банкрутство, затвердженим постановою Кабінету Міністрів України від 2 жовтня 2019 року № 865 (далі - Постанова). 
У науці питанням організації продажу майна банкрута приділяли увагу Аляб'єва Н. В., Балакін В. В., Бєляєва О. А., Романюк Я. М., Дудник Д. В., Мартинюк О. А., Зеленкова І.І., та інші. Проте оновлення законодавства актуалізує питання організації продажу майна банкрута, зокрема, з метою конкретизації етапів такої організації.

Електронні торги - це продаж майна за принципом аукціону через Веб-сайт, за яким його власником стає учасник, який під час торгів запропонував за нього найвищу ціну. Дана сучасна реалізація майна боржника на електронних аукціонах відповідає загальній тенденції міжнародного ринку на конкурентних, відкритих та загальнодоступних засадах.

3 запровадженням нових правил продажу майна, замовником аукціону $є$ арбітражний керуючий, який призначений господарським судом у порядку, встановленому законом. Першим етапом в організації продажу майна банкрута виступає укладання договору про проведення аукціону між замовником і організатором. Далі замовник в системі, через свій особистий кабінет, створює інформацію щодо майна та формує відповідний лот. Так, відповідно до Кодексу, оголошення про проведення аукціону здійснюється впродовж 20 календарних днів 3 моменту отримання погодження на продаж. Лот формується за такими характеристиками як: тип, найменуванням, вид, назва, місцезнаходженням майна, початкова ціна, дата проведення аукціону й публікація оголошення про нього, номер справи про банкрутство та найменуванням сторін. Замовник аукціону визначає дату і строк проведення аукціону, що відраховується з моменту опублікування оголошення про проведення аукціону в системі, з урахуванням початкової ціни майна та виду аукціону. Дата та час початку проведення аукціону зазначаються в оголошенні про проведення аукціону, яке розміщується на веб-сайтах автоматично після формування лота у електронній платформі [1].

Перелік авторизованих електронних майданчиків, тобто самої «nлатформи продажу» із зазначенням їх веб-адрес і операторів міститься в електронній торговій системі. Такий авторизований електронний майданчик повинен забезпечувати: можливість пошуку інформації за датою розміщення оголошення, датою проведення аукціону, видом майна, ціною, номером лота, місцезнаходженням майна, найменуванням боржника та замовника аукціону; можливість анонімного цілодобового перегляду, копіювання та роздрукування інформації на основі поширених веб-оглядачів та редакторів без необхідності застосування спеціально створених для цього технологічних та програмних засобів, без обмежень та стягнення плати; автоматичне розміщення, отримання і передачу інформації та документів; 110 
користування сервісами з автоматичним обміном інформацією; рівний і вільний доступ до аукціону всім учасникам та можливість здійснювати перегляд проведення аукціону в інтерактивному режимі реального часу всім заінтересованим особам [2].

Так, електронною платформою $з$ продажу майна боржників є ДП «Прозорро.Продажі». Система є загальнодоступною та працює цілодобово. Інформація, яку вона містить, є вільною та безоплатною для доступу користувачів. Платформа дає можливість постійного та відкритого доступу до проведення аукціонів з метою спостереження за ї ходом та результатом. Іншою досить популярною платформою $\epsilon$ майданчик Е-Тендер, який теж в свою чергу є авторизованим та підключеним до системи Прозорро, що не заважає організовувати такі аукціони та брати участь у них [3].

Наступним етапом організації продажу майна банкрута можна назвати реєстрацію учасників. Для участі в аукціоні заявник проходить процедуру реєстрації на веб-сайті, подає заявку на участь в аукціоні за кожним лотом окремо, сплачує гарантійний внесок на рахунок оператора. Заява на участь в аукціоні повинна містити закриту цінову пропозицію, крім аукціонів з можливістю зниження початкової ціни лота. Треба зазначити, що будь-яка інформація про кожного учасника аукціону є знеособленою (анонімною) до закінчення аукціону.

Іншим етапом організації продажу майна $\epsilon$ проведення електронного аукціону. Аукціон проводиться з метою визначення переможця, в ході якого його учасники мають можливість поетапного збільшення своїх цінових пропозицій протягом трьох раундів.

Потрібно зазначити, що замовник має право скасувати аукціон до моменту початку торгів лише у разі порушення його порядку підготовки. Тоді він протягом 10 робочих днів має оголосити про проведення нового. Причини скасування аукціону замовник зазначає в інформації про це через електронний майданчик. Якщо аукціон було скасовано, оператори авторизованих електронних майданчиків повертають учасникам сплачені ними внески не пізніше трьох банківських днів.

Після визначення переможця аукціону системою формується протокол про проведення аукціону, який надсилається всім учасникам та замовнику аукціону. Оригінал протоколу підписується оператором авторизованого електронного майданчика та переможцем. Після підписання протоколу оператор електронного майданчика не пізніше п'яти календарних днів розміщує його в торговій системі. Замовник аукціону через свій особистий кабінет повідомляє оператору про повний розрахунок переможцем аукціону на придбане майно не 
пізніше наступного робочого дня 3 дня надходження коштів на рахунок боржника. Отже, метою зазначених етапів організації аукціону $\epsilon$ отримання коштів від продажу майна, за допомогою яких здійснюється погашення боргів перед кредиторами.

На підставі викладеного можна зробити висновок, що організація продажу майна банкрута складається 3 низки послідовних етапів, зокрема: спочатку замовник укладає договір про проведення аукціону із організатором, надалі він отримує доступ до електронної торговій платформи через акредитований електронний майданчик, іншим етапом здійснюється формування та публікація лоту в системі відповідно до вимог Кодексу та Постанови, з моменту публікації і до проведення електронного аукціону зацікавлені користувачі подають заявки, сплачують гарантійні внески та беруть участь у самих аукціонах, після визначення переможця формується протокол, який підписується переможцем та оператором майданчика, результатом успішно проведених торгів $\epsilon$ акт про придбання майна на аукціоні, який завантажується в систему. Дотримання нормативно-правових вимог щодо кожного 3 етапів $є$ важливим, оскільки від цього залежить кількість осіб, які беруть участь та можуть запропонувати найвищу ціну та результат продажу майна, за допомогою якого здійснюється погашення боргів перед кредиторами.

Напрямом подальших досліджень можуть виступати питання договірних відносин між замовником та організатором аукціону, оскільки законодавством не чітко врегульовано та закріплені норми, стосовно таких договірних відносин, так потребує вивчення та виокремлення основних ознак, які притаманні саме договору про проведення аукціону в процедурі банкрутства.

\section{Література:}

1. Кодекс України з процедур банкрутства: Закон України від 18 жовтня 2018 № 2597-VIII. Законодавство України. URL: https://zakon.rada.gov.ua/laws/show/2597-19

2. Постанова Кабінету Міністрів України «Питання функціонування електронної торгової системи 3 продажу майна боржників у справах про банкрутство (неплатоспроможність)» [Електронний peсурс] // № 865 від 2 жовтня 2019 p. URL: https://zakon.rada.gov.ua/ laws/show/865-2019-\%D0\%BF\#Text

3. Аукціон 3 продажу майна банкрутів. E-tender. URL: https://e-tender.ua/training-e-auction/uchasnik-aukcionu-2/aukcion-zprodazhu-majna-bankrutiv-23 (дата звернення 01.02.2021). 